\title{
Role of Forest Related Policies and Laws on Sustainable Forest Management Practice: A Critical Overview
}

\author{
Gordon Kofi Sarfo-Adu \\ Forestry Commission, Corporate Planning Manager
}

\begin{abstract}
Following the rate with which forest resources get degraded, increasing attention has been paid to the conscious and sound efforts towards mainstreaming appropriate interventions to halt the menace. Following the United Nations Conference on Environment and Development held in Rio 1992, the idea of sustainable forest management has become popular in the international arena which admonishes various member-states and local governments to adopt policies and laws to enhance sustainable forest practices. The idea of SFM has been reinforced by the recent Reducing Emissions from Deforestation and forest degradation sustainable biodiversity management (REDD + ) policy. In that regard, attention to laws, policies and institutions towards sustainable forest management has increased. This paper adopts a desk review approach to assess the role of forest-related policies on sustainable forest management practices. Essential tools and strategies for SFM are discussed, including measures to enhance enforcement of SFM policies and procedures. The study argues that actor constellation; autonomy to local actors and external actors involved are crucial in the drive towards sustainable forest management.
\end{abstract}

Keywords: sustainable forest management; policies; institutions; community involvement; enforcement

DOI: $10.7176 / \mathrm{JRDM} / 73-06$

Publication date: February $28^{\text {th }} 2021$

\section{Introduction}

National forest policies and participatory action plans are critical to sustainable forest management (McDonald \& Lane, 2004). Scholars and practitioners have argued for a need to incorporate measures that seek to sharmonise between forest resources protection (ecological) on the one hand, and people's reasonable usage for socioeconomic purposes on the other hand (Gbedomon et al., 2016; Silva \&Mosimane, 2013). This has given rise to the idea of Sustainable Forest Management (hereafter, SFM) which suggests a management system that 'seeks to balance the social, economic and ecological values associated with forest, with consideration of these values for future generations' (Hickey, 2008 p. 109). Arriving at this ideal nexus remains the greatest challenge facing policymakers and foresters which calls for robust forest policies and laws, functional access and tenure rights together with a useful institutional underpinning to help drive sustainable behaviours towards forests (Ceddia et al., 2015). Other scholars (Sundar, 2000) posit that even in situations where there are forest-related laws, policies and access right, the enforcement may not adequately and profusely elicit the best of results when exclusively left to the formal state regulators, especially in the developing world.

From the foregoing, promoting sustainable forest management requires an interplay between formal state actors, non-governmental actors and entire citizenry; and that these must proactively help in the effective enforcement of forest policies and laws. Within such context, the literature maintains that a network of actors rather than the government alone makes forest policy decisions effective (Lebel et al., 2006), helps in resolving trade-offs and provision of a vision and direction for forest sustainability drive (Boyle et al., 2001). Many people, communities and groups depend on forest resources for their livelihood and socio-economic development. In other words, forests provide value for people, therefore, if there are no functional policies and laws, people and groups will approach forests with exploitative tendency to maximise the gains from wood products in the forests leads to the destruction of global and national forests.

As human population and per-capita consumption grow, this has caused increasing pressure on forests for timber, food and bio-fuels (Edwards et al., 2014; Laurance et al., 2014). Global demand for and consumption of timber is mostly high partly due to the growing timber markets in Asia and other developing economies (FAO and ITTO, 2011). There has been a global forest decline between 1990 and 2015, from 31.7 per cent of the world's total landmass to 30.7 per cent (United Nations Department of Economic and Social Affairs, UN-DESA, 2016). Between 1990 and 2015, there has been a total forest decline from approximately 706 million ha to 624 million (FAO 2015). Against such background, SFM emerged as a critical strategy for conservation and economic development in tropical forest regions worldwide during the 1992 United Nations Conference on Environment and Development (UNCED) held in Rio (FAO \& ITTO, 2011). Since this summit, SFM has been embraced by governments, production organisations, conservationists, consumers, and development NGOs alike (Amsallam et al., 2003; deWasseige et al., 2012; Lambin et al., 2014; Putz et al., 2012). Sustainable Forest Management (SFM) - the process of managing permanent forest land for timber production without reducing inherent values and future productivity - is viewed as a critical component of forest protection, biodiversity conservation and income enhancement in tropical forests. 
Many forests have been depleting at an alarming rate which suggests a prudent approach that elicits sustainable forest drive is crucial. The argument is that effective and efficient management of forest resources calls for management practices and rules underpinned by legitimate forest policies and laws (FAO, 1994; FAO, 1998). Such policies and forest laws need to be designed in such a way that will safeguard incessant protection of forests services while optimising forest resource use (FAO, 1998; Hughes \&Flintan, 2001). Legislation and policies are pivotal in the management of natural resources (FAO, 2010), and it has been demonstrated that continued degradation and depletion of global forests are largely attributed to high-levels of policy failure and dysfunctions in national legal regimes to enforce protective measures (Van Lavieren et al., 2012). In other words, addressing the common challenges that bedevil the forest sector and to rise to the task of reducing forest degradation and deforestation (REDD+) concept, the issue of policy and rules have become crucial in the forest literature. Regarding the forest sector, such policies entail laws, regulations, rules, norms, and standards of good forest practice.

Noting the relevance of policies and laws, this study seeks to draw from classical theoretical and recent empirical studies on the phenomenon to assess the role of forest policies and related regulations in sustainable forest management. The driving research questions are clear cut. How do forest-related policies and laws influence sustainable forest management in developing countries? What lessons could be drawn from recent empirical experiences on the interplay of laws/policies and SFM in developing countries? Beyond this introduction, the rest of the paper is sorganised as follows. Section two is dedicated to a rigorous review of the literature on sustainable forest management, while section three discusses the methodological approach underpinning the study. The results of the research and discussion are presented in section four with conclusions that can be distilled from the paper presented in section five.

\subsection{Conceptual review and theoretical framework}

The concept of Sustainable Forest Management

The idea of SFM has been given a classical definition by the International Tropical Timber Organization to mean the process of managing permanent forest land to achieve one or more specified objectives of management about the production of a continuous flow of desired forest products and services without undue reduction of its inherent values and future productivity and undesirable effects on the physical and social environment". (ITTO, 1992, p. 32). This is also rooted in the sustainable development goals, which among other things, seeks to ensure harmony between social, economic and ecological values. This is also the central pillar of the REDD+ aimed at reducing forest degradation and deforestation as well as providing biodiversity protection. On their part, the Food and Agricultural Organization defines SFM as one which ensures that the values derived from forest meet present-day needs while at the same time ensuring their continued availability and utilisation to long-term development needs (FAO, 1993). From the definitions above, SFM connotes the stewardship and use of forests and forest land in a way and at a rate that maintains their biodiversity, productivity, regeneration capacity, vitality and potential to fulfil, now and in the future, relevant ecological, economic and social functions, at local, national and global levels and does not cause damage to other ecosystems

\section{Institutions and sustainable forest management}

Forest resources have many uses, and different stakeholders appear to have mixed use of forest resources. In that regard, encouraging sustainable forest management calls for a regulatory framework which provides clear rules of the game" regarding what, how, when and how much of a resource one could access at a time. The role of institutions is very crucial in this sustainable forest management drive. Institutions are defined to mean man-made regulative structures for moderating human behaviours and relationships and coordinating decisions toward a desired goal; in other words, institutions are formally sanctioned rules of a society, which provide expectations, stability, and meaning to human relationships (Vatn, 2005; North, 2007). Institutions are rules and regulations that structure how people relate to forest and its resources or how the actors relate to each other for sustainable forest management. According to Wiering and Arts (2006), sustainable forest management regulations indicate the extent to which changes in forest management discourse are reflected in changes in general regulation or the manifestation of policy content into formal rules. As a general precaution, it is prudent to assess the extent to which there is a congruence between formal rules/regulations and informal rules or conventions of society. In that regard, scholars (Gunningham\& Young, 1997) argue for a careful assessment of other related policy discourses if an attempt in such regard generated some 'perverse consequences' in the past. This is crucial to ascertain the level of rule acceptance 'a priori'. Rule acceptance indicates the congruence between formal and informal practices (Poteete\&Ostrom, 2004). A legal rule that has 'high congruence' engenders legitimacy from community members and other stakeholders and is more likely to elicit willing compliance. On the other hand, 'low congruence' suggests the formal rule or directive enjoys less legitimacy and could only be enforced by coercion which might not be sustainable. In short, the likelihood for SFM policy or regulations to be efficaciously administerimplemented enhances when the SFM discourse is regularised in rules, and the resulting rules are accepted, which suggests the 
formal rules are congruent with the information practices or norms of society.

\section{The Institutional and Development (IAD) framework}

The Institutional and Development (IAD) framework by Ostrom (1990) has been used to explain forest-related studies. The structure examines how the interaction between forest resources and forest policies/laws influence forest outcomes (sustainable forest management or otherwise). It provides the theoretical underpinning to a fundamental question of how biophysical elements interact with related rules and policies (both formal and informal institutions) to influence the behavior of stakeholders or actors towards natural resources. The role of institutions is crucial in the ordering of human relations, preferences and choices. The institutional arrangement is defined as the interplay of formal legislation and informal practices and conventions (North, 1991). This arrangement together with the subsequent processes collectively provides a framework that shapes natural resources and also provides incentives that determine how people behave and interact with the resource and among themselves.

The institutional process remains the cornerstone for social interaction which assigns roles, enhances actions and also constrains behaviours; they are also critical to the decision making process and determinant of the extent to which decision making should be open or close, who should be involved as well as determines how conflicts are managed in society (North, 1991). Institutions have deliberately been designed with societal and sorganisational embedded values, interests, goals, and resources that constrain or enable human behaviour in society (North, 1991; Hodgson, 2006; Leftwich\& Hogg, 2007). The role of institutions has been argued by Kiser and Ostrom (1982) who esemphasise that three layers of rules (constitutional rules, collective choice rules and operational rules) shape every institutional arrangement. They explain that constitutional rules specify the terms and conditions for governance by stipulating who possesses the decision right concerning access and sutilisation of a resource as well as who is eligible to share the benefit of its use. The authors explain that collective choice rules tend to shape and regulate the processes of decision-making. For example, regulations to determine how much of a resource to be harnessed and what technology is allowable and detestable. The authors end by providing that operational rules regulate the daily activities, for instance, the intensity of harvesting or methods of cultivating. The process and institutional element prudently identify scope for relevant stakeholders sorganise and carry out their tasks orderly and also to maintain mechanisms to adequately address major communal or sectional concerns through a collaborative process.

An essential part of the institutional process is the enforcement mechanism which, according to Gibson et al. (2005) is fundamentally crucial for the desirable outcomes in sustainable forest management. While other factors, such as high level of social capital, presence of the formal organisation, and peoples' degree of dependence on forest products, Gibson et al. (2005) rate institutional enforcement and monitoring as more critical for a sequential improvement of forest management interventions. North (2003) provides that achieving effectiveness through institutionalism involves interplay between three essential elements; the formal rules, informal norms and their enforcement characteristics. Institutions or policies are not relevant if they are unable to structure human interaction; without the tools, skills and personnel to maintain a link between rules/policies and their enforcement to enable or constrain human actions sufficiently, institutions become useless.

\section{Methodological approach}

This paper uses arguments and observations from existing theoretical and empirical studies, which have been drawn from journal articles and relevant materials/resources to examine the role of forest policies and legal regimes in sustainable forest management. The paper adopted secondary materials and sources to assess critical themes and trends in recent empirical studies on the phenomenon primarily from developing country context, albeit, observations from developed contexts have been used for some form of comparison and to enhance the analytical rigour. The literature search covered all terms and terminologies as approximately related to sustainable forest management: SFM", "sustainability and forests", "sustainable forests", "sustainable practices and forests", and "Sustainable forest management". The author did include adjectives related to the promotion of sustainable forests; the words added 'booming' 'enhanced' 'sustained' 'successful' 'effective'. The different adjectives and the concept of sustainable forests (SFM) were combined variously to obtain a pool of more relevant literature on SFM and forest policies/laws. The following three search engines predominantly resorted to based on their relevance to the topic area and accessibility to the researcher: Sciencedirect, Tandonline, and Google Scholar. The large pool of articles from these sources was initially sorted for relevance by skimming through their abstracts. At the end of this initial screening process, irrelevant materials were eliminated, and a shortlist of summaries for detailed and systematic review was done. The observations from these resources have been used to elicit critical themes classified in the discussion section of this paper, which is adequately examined with the help of empirical observations from recent literature. 


\section{Discussion}

What has resulted in the growing need for policies and rules is the ever increasing levels of rapid deforestation taking place across countries and which has had profound implications for rural populations who rely heavily on forest resources for livelihoods (Chan \& Sasaki, 2014; Ehara et al., 2016; GERES, 2015). Increasing attention to policies, rules and regulations with emphasis on how these could help engender sustainable forest management (SFM) practices. By SFM practices, it connotes formulation and adoption of relevant institutions; implementation and monitoring of these institutions; Institutional capacity for country ownership; stakeholder involvement (including civil society); and broad intersectoral approach. It also entails fight against illegal logging; market pressure such as EU Timber Regulation, forest certification among others. This section discusses lessons derived from empirical studies from across different contexts regarding forest-related policies and sustainable forest management.

\subsection{Tools for Sustainable Forest Management}

SFM has been encouraged as a critical guiding principle in managing forests (ITTO, 2006). The concept guides how to manage forests to cater to today's needs appropriately without compromising the options of future generations (Forest Principles, UN Rio, 1992). The tools were available for encouraging SFM to begin with policy and regulations that support those who are practising forest management. They also include inventories, monitoring, forest management certification, stakeholder involvement and forest management plans. Essential tools and principles for SFM are discussed below:

\section{Forest Management Plans (FMPs)}

There is broad consensus that Forest Management Plans (FMPs) are a critical first step toward achieving SFM in the tropics (FAO and ITTO, 2011). An FMP is a detailed plan for selective logging of a prescribed area for a specific amount of time. It is designed to encourage optimal harvest rates without compromising the required for maturation of new harvestable specimens before the next logging cycle (Armitage, 1998). The FMP model originated from Germany in the 1700s in response to acute local timber scarcity. According to Holzl (2010), the FMP was adopted by the Germans to enhance long-term timber abundance. The use of FMP as a tool for SFM is very indicated as FMPs clearly define allowable cutting zones and timber volumes, enabling governments to monitor and regulate timber extraction, thus preventing forest clearing due to overexploitation or agricultural expansion (Bell et al., 2012; Ezzinede Blas and Perez, 2008). Finally, by safeguarding long-term timber stocks, land rents for sustainably-managed natural forests remain competitive with rents for alternative land uses in the future, thus preventing eventual conversion to agriculture, pasture, and plantation forests (Blaser et al. .2011; Phelps et al., 2013). This model is gradually finding their way in the tropics since it has proven to an appropriate tool. For instance, Agrawal, (2005) reports that since the early 19th Century, FMPs have been attempted with varying implementation experiences for tropical forests (also Nasi \& Frost, 2009). Consequently, the area of tropical forests managed through FMPs increased by 30\% from 2005 to 2010, and now total 183million hectares worldwide, or $46 \%$ of tropical production forests (Blaser et al., 2011).

\section{Forest certification and Supportive legal and regulatory regime for SFM}

These international and regional initiatives and research efforts have made good progress in using science, commerce and social values to devise their indicators. Supportive national legal, policy and institutional frameworks can make SFM practices cost-effective and when effectively applied to encourage the methods needed for SFM (Keeton \& Crow, 2009; FAO, 2010; Lovrc et al., 2010). Forest management certification provides independent, third-party verification of adherence to a defined set of management standards that promote and measure SFM (CEPI, 2006). The practice of sustainable forest management is enhanced by the useful application of a national legal, policy and institutional framework. Countries that had either policies and or legislation that support sustainable forest management cover $99 \%$ of global forest area

\section{Payments for ecosystem services}

This strategy has proven more useful especially in Mexico and Costa Rica, which appear to possess the most exceptional state capacity and the clearest property rights for forest land - the requirements for effective payment system- (Busch \&Ferretti-Gallon, 2017). The authors, in their review of literature, examine the impact of payment for ecosystem services on forest cover. All cases of PES in their analysis noted positive results on forest cover, and these were predominantly from Mexico and Costa Rica. Other empirical studies (Robalino\& Pfaff, 2013; Sanchez-Azofeifa et al., 2007) from the same context noted low avoided deforestation as a result of payment programs but further noted improvements in impacts over time. This suggests that such a strategy of payment for ecosystem services is very useful and crucial for sustainable forest management. 


\section{Role of community}

Forest sdecentralisation has mainly been applied to low-value forests, as most governments tend to retain control of high-value forest; and high-value timber concessions get assigned to the private sector. Income flows from timber concessions go to the State, and there is a lack of willingness to sdecentralise such forest lands to either comanagement or community ownership regimes (Barrow et al. 2009). Such practices have not been compatible with the drive to SFM because the role of communities is crucial. Barrow et al., (2016) contend that rural communities need rights to, and responsibilities for the sustainable management of forests, be able to decide on the value of such resources, identify enterprises, seek financial and technical support for developing such enterprises, and establish and nurture sustainable institutions that assure more equitable benefit accrual. To foster sustainable forest management practices, the role of communities, their participation and empowerment has been described as very essential to SFM drive. For example, new forestry policies and laws formulated in Cameroon, DR Congo, Gabon, Equatorial Guinea, the Central Africa Republic and the Republic of Congo Brazzaville (CBFP 2006) take into account the rights of local communities in forest management and access to associated benefits (Karsenty 1999 , 2004; Oyono 2007). They are oriented towards sdecentralisation (CBFP 2006; Oyono, 2007), but many such policies are yet to be implemented (White \& Martin 2002; Oyono 2007). Recognising communities and indigenous people's rights are essential for advancing human rights, alleviating poverty and conserving the forest.

\section{Land tenure, actor engagement and SFM}

Forest management systems that effectively engage citizens in forestry make more resilient and sustainable decisions because of the trust and support that inclusive governance brings (Azevedo et al. 2014). There is a growing literature in support of the proposition that strong indigenous and local tenure is associated with forest management outcomes that are at least as good or better than results for areas owned and managed by the State, such as protected areas (Seymour et al. 2014). In other words, where the security of tenure has been strengthened, communities have demonstrated active participation in forest management. On the other hand, where active stateState strongly controls the land, communities may rarely participate in forest management activities, but will not invest (Seymour et al., 2014). Forest tenure reform provides rural people with rights to access and use of forest resources which contribute to improved forest management and poverty alleviation. But, at least to poverty alleviation(Fisher et al. 2012). More modest locally negotiated changes and local 'informal' arrangements can lead to improved access to forests and provide people with the confidence that enables them to invest time and resources in forest management, for example, tree registration in Ghana, piloting joint forest management (Fisher et al. 2012)

\section{Empowering community people and promoting alternate livelihoods}

Security of forest tenure rights should be complemented by enabling measures to build technical, financial, managerial capacities, access to technologies and markets. Non-timber forest products and small-scale timber enterprises can provide extensive, alternative economic activities, contributing substantially to the rural economy and employment. Economic growth, private investment and poverty alleviation should complement each other, and this cannot be achieved through decentralised rights and responsibilities, and 'managing' the forest on their own. Instead, the ability and capacity of rural communities to invest and enter the market on a fair and competitive basis will lay the foundation for success.

In the early 20th century, Gifford Pinchot recognised that clear and convincing evidence was needed to demonstrate that sustainable forest management would return a profit. He also noted that sustainable forestry was not possible without the consent and active participation of the public (Schmithüsen, 2013) and adequate provision should be made such that SFM would yield benefits or returns to local people.

\section{Binding contracts for private sector involvement}

Garret Hardin's "tragedy of the commons" makes the case why private ownership is preferable to the common property: "Ruin is the destination towards which all men rush, each pursuing his own best interest in a society that believes in the freedom of the commons" (Hardin, 1968, cited in Ostrom, 1990, p. 2). Private property owners have higher incentives to use resources efficiently and sustainably (Demsetz, 1967; Tucker, 1999); however, private property does not guarantee efficient and sustainable resource management because owners may act with poor judgment, or depending on their circumstances, they may not place importance on a resource's future value (Brouwer, 1995). Within existing theoretical and empirical positions for governing natural resources, either on shared or private property, the solution to unsustainable behaviour (avoiding a "tragedy of the commons" or "freerider situation") is either through the imposition of regulation by the government following Hobbes's solution of the imposition of a leviathan (Ophuls, 1973) or a self-sorganised community institution (Ostrom, 1990). The latter is based on the principle of cooperation, a way through which cooperative solutions could be devised to problems without the intervention of a coercive state. In this case, private forests owners will make a binding contract (an institution) to commit themselves to a cooperative strategy that they will work out (Ostrom, 1990). 
Role of Civil Society

Civil society sorganisations are key players as they can deliver and facilitate policy provision to local communities, and can help improve governance, transparency, environmental management and human rights. They help step up the actions of governments, the private sector and other actors, which can provide for better decentralisation, and enable rural communities to enter the market place and create wealth for sustainable forest management (Barrow et al. 2009).

\subsection{Role of forest-related policies and laws}

Policies are very crucial in the SFM drive. Procedures are defined to mean the formally codified outputs that governments and their agencies adopt to deliver particular measures towards the enforcement of an objective or purposive action (Anderson, 2003; Birkland, 2005). Governmental forest regulation is usually passed and enforced to avoid resource exhaustion and to promote long-term values which may not be adequately provided by markets (Cubbage et al., 2007). State regulation of forest use usually sets a minimum standard which determines allowable and proscribed forest practices (Moffat \&Cubbage, 2001). Such rules may involve (i) determination of voluntary or mandatory technologies towards SFM through performance standards or best management practices to be followed by forest users. Such best management practices include (i) stipulated guidelines for tree harvest plans, (ii) extraction, and reforestation processes, (iii) management and handling of endangered species and their habitat (Moffat \&Cubbage, 2001; Louman, Quiros, \& Nilsson, 2001). Such forest regulations are very crucial to the SFM plan, and the extent to which these regulations are enforced determines the relevance. For instance, Cashore and McDermott (2004) adopt a cursory analysis of the operational content and experiences of forestry regulations from twenty developing and advanced countries context. The authors note that the extent to which a policy incorporates substantive requirements prescribing specific forest practices through specific measures determine the impact on SFM.

\subsection{Enhancing the enforcement of SFM policies}

Actor constellation and cooperation

Enforcing SFM institutions or rules calls for interaction between key stakeholders and players in the governance process including, the state agencies or enforcement agencies, private sector or companies, civil society, and local community members (leaders, farmers, others resource users, groups). Critical elements for successful collaborative governance in this process are (i) trust in guaranteed cooperation (Meyer \&Baltes, 2004; Buizer, 2008) and information exchange (Edelenbos\&Klijn, 2007). The robustness of actor relations, which produces the 'trust' criterion is underpinned by a more or less stable perception of actors about the intentions of other parties. This has been underscored by Edelenbos and Klijn, (2007) who postulate that actors or groups refrain from opportunistic behaviour. In that regard, promoting SFM calls for measures to uphold provisions and promises made to each party, especially local community members regarding access rights, tenure and other benefits to be derived from the forest resource. This is crucial to uphold and build up the trust, which is a pre-requisite for success. Knill (2000) contends that trust is vital for SFM since collective action only becomes feasible and workable if trust and reliability of each member in the network can be guaranteed. Building trust entails these:

(i) Regular interactions, information communication and previous trustworthy relationships (Dasgupta, 2000; Hardy et al., 1998),

(ii) the expected shared gains of cooperation (Hardin, 1991; Kramer et al., 1996)

(iii) Respect and acknowledgement of others' knowledge and using it in an appropriate way (Charnley et al., 2007).

\section{Enforcement prowess}

Carrying out sformalised rules or institutions entails a well-sorganised team, or agency that is up to the task. The key includes sformalised and in sformalised authority, financial resources and human resources (Liefferink, 2006), expert power (knowledge), ownership power (Finkelstein, 1992) and communication possibilities. These are critical requirements for agencies to appreciably carry out active SFM initiatives and logically enforce such actions.

\section{Autonomy}

Autonomy from external influence in crafting and enforcing rules, the rate and intensity of external use and conflicts, and the organisation of monitoring, enforcement and maintenance activities have been emphasised as conducive for SFM (Baynes et al., 2015). At the individual level, Van Laerhoven (2010) highlights three collective action activities that individuals can participate in: (a) meetings and public spaces where SFM rules and policies are deliberated; (b) monitoring and enforcement of regulations; and (c) forest maintenance activities for commercial or conservation purposes. In the context of devolution programmes, individuals must have access to information to take advantage of potential opportunities (Larson \& Soto, 2008). 


\section{Interplay between institutions}

Attention to inter-institutional linkages, prevailing informal constraints on forest use, and diverging interests in forestland and resource use are necessary considerations for SFM initiatives to institutionalise effective forest governance. Specifically, monitoring and enforcement arrangements, as well as the distribution of associated burdens between stakeholders, should favour autonomy and create conditions for institutional innovation and adaptive co-management (Bixler, 2014).

\section{Role of external actors}

In general, external facilitators including NGOs should focus on enhancing conditions for collective action and institutional learning in the community context, and move away from assisting technocratic formalisation (Baynes et al., 2015; IHRCRC, 2015). Particular attention should be paid to ensuring more significant inclusion in decisionmaking processes, specifically focusing on remote and worse-off households and women, by improving information exchange mechanisms

\section{Laxities in SFM policies Corruption and forest policies}

A key factor that undermines the drive towards SFM is corruption which entails collusive action between some forestry officials and unscrupulous non-state actors who operate at the blind side of the rules or regulations. In most cases, the latter are economically and politically connected. These resources culminate into a complex political economy of the timber industry where deforestation is encouraged through the gradual construction of a state "built on patronage, corruption and coercion" (FAO, 2010; Forests Trends, 2015; Miranda \& Kool, 2007, p. $10)$.

Governance in developing countries is often weak, and thus the institutional structures necessary to monitor and enforce policies are often lacking.

This results in a situation where there is a reorganisation of productive networks outside the formal institutional arena where illegal activities occur (Billon, 2001) and such patronage activities put significant pressure on the allocation of those booties accrued through this unorthodox system prevalent in the forestry industry (Milne, 2015). The critical point expressed here is that the drive towards SFM requires effective forest policies that are well enforced to elicit compliance and corresponding forest health; however, there are mostly reports of regulatory failures which are commonly attributed to corruption, and weak legal systems (ContrerasHermosilla, 2002; Hickey, 2004; Cashore\& McDermott, 2004). As a result, international organisations and governments are increasingly investing in official record-keeping of compliance and timber production to promote transparency of logging operations (Blaser et al., 2011; FAO and ITTO, 2011). Examining the impacts of natural resource policy is challenging in tropical regions of developing countries (Lambin et al., 2014; Milder et al., 2015). First, logging often occurs in vast, remote, inaccessible regions, and thus the on-the-ground measurement of logging impacts is challenging. While a site-based investigation is essential, in practice, only a fraction of the area impacted can be investigated, leaving us uninformed about the universality of the observed impacts. As a result, governments, scientists, and international organisations are investing more and more in creating satellite-derived measurements of deforestation (Hansen et al., 2013; Xin et al., 2013).

\section{Conclusion}

The study sought to examine the role of policies and laws in sustainable forest management drive. From a critical review of literature, it is noted that increasing need to reduce forest degradation necessitates the establishment of forest-related policies which are deemed very crucial for SFM. The study has reviewed the literature on the roles played by forest policies and institutions as well as the significant constraints faced in their execution. More importantly, the paper has discussed essential tools for sustainable forest management which, when adopted in a more holistic and taking into account the specific context, will help a long way to drive sustainable forest outcomes. The critical policy drivers that are crucial for SFM practices are the establishment of Forest Management Plans (FMPs), Forest Certification Schemes, Payment for Ecosystem Services, Community Engagement, Land Tenure Arrangements and Alternative Livelihood Programs. The study observes that key laxities in the enforcement of SFM and consequently advances vital measures to counter them. These include Actor Constellation; Autonomy to local actors and External Actors involvement.

\section{REFERENCE}

Amsallem, I., Wilkie, M.L., Kone, P. and Ngandji M. (eds.) 2003. Sustainable Management of Tropical Forests in Central Africa. FAO, Rome.

Anderson, J. E. (2003). Public policymaking. Cengage Learning.

Azevedo T, Purnama B, Bosworth D, Collins S, Farrell J, Kanel K,Konkin D, Torres-Rojo J. 2014. Public forest agencies in the twenty first century. Washington (D.C.): Megaflorestais, Rights and Resources Initiative 
Barrow E, Jones K, Nhantumbo I, Oyono R, Moumini S. 2009. Customary practices and forest tenure reforms in Africa - status, issues and lessons. Washington (D.C.): Rights and Resources Initiative.

Barrow, E., Kamugisha-Ruhombe, J., Nhantumbo, I., Oyono, R., \&Savadogo, M. (2016). Who owns Africa's forests? Exploring the impacts of forest tenure reform on forest ecosystems and livelihoods. Forests, trees and livelihoods, 25(2), 132-156.

Baynes J, et al. 2015. Key factors which influence the success of community forestry in developing countries. Global Environmental Change 35:226-238.

Baynes, J., Herbohn, J., Smith, C., Fisher, R., \& Bray, D. (2015). Key factors which influence the success of community forestry in developing countries. Global Environmental Change, 35, 226238.

Bell, A. R., Riolo, R. L., Doremus, J. M., Brown, D. G., Lyon, T. P., Vandermeer, J., \& Agrawal, A. (2012). Fragmenting forests: the double edge of effective forest monitoring. Environmental science \& policy, 16, 2030.

Birkland, T. A. (2005). An Introduction to the Policy Process: Theories. Concepts, and Models of Public Policy Making, ME Sharpe, New York, NY, 111.

Bixler, R. P. (2014). From community forest management to polycentric governance: assessing evidence from the bottom up. Society \& Natural Resources, 27(2), 155-169.

Blaser, J., Sarre, A., Poore, D. et al . (2011) Status of tropical forest management 2011. ITTO Technical Series 38 , International Tropical Timber Organization, Yokohama, Japan

Boyle, M., J. Kay, and B. Pond. 2001. Monitoring in support of policy: an adaptive ecosystem management approach. Pages 116-137 in M. K. Tolba, editor. Encyclopedia of global environmental change. Volume 4: responding to global environmental change. Wiley,Chichester, UK.

Brouwer, R. (1995). Common goods and private profits: Traditional and modern communal land management in Portugal. Human Organization, 54(3), 283-294.

Buizer, I. M. (2008). Worlds apart: interactions between local initiatives and established policy (No. 22). AlterraWageningen UR.

Busch, J., \&Ferretti-Gallon, K. (2017). What Drives Deforestation and What Stops It? A Meta Analysis. Review of Environmental Economics and Policy, 11(1), 3-23.

Cashore, B., \& McDermott, C. (2004). Global environmental forest policies: Canada as a constant case comparison of select forest practice regulations. Retrieved from http://www.bcforestinformation.com/sustainable$\mathrm{mgmt} / \mathrm{managing}$-forsustainability/documents/Jurisdictional_Comparison.pdf

Ceddia M G, Gunter U and Corriveau-Bourque A 2015 Land tenure and agricultural expansion in Latin America: the role of indigenous peoples' and local communities' forest rights Glob. Environ. Change 35 316-22

Charnley, S., Fischer, A. P., \& Jones, E. T. (2007). Integrating traditional and local ecological knowledge into forest biodiversity conservation in the Pacific Northwest. Forest Ecology and Management, 246(1), 14-28.

Contreras-Hermosilla, A. (2002). Law compliance in the forestry sector: an overview. World Bank.

Cubbage, F., Harou, P., \& Sills, E. (2007). Policy instruments to enhance multi-functional forest management. Forest policy and economics, 9(7), 833-851.

de Blas, D. E., \& Perez, M. R. (2008). Prospects for reduced impact logging in Central African logging concessions. Forest ecology and management, 256(7), 1509-1516.

De Wasseige, C., De Marcken, P., Bayol, N., Hiol-Hiol, F., Mayaux, P., Desclée, B., ...\&Atyi, E. A. (2012). The forests of the Congo basin: state of the forest 2010 (p. 276p). Publications Office of the European Union, Luxembourg.

De Wasseige, C., De Marcken, P., Bayol, N., Hiol-Hiol, F., Mayaux, P., Desclée, B., ...\&Atyi, E. A. (2012). The forests of the Congo basin: state of the forest 2010 (p. 276p). Publications Office of the European Union, Luxembourg.

Demsetz H. 1967. Towards a theory of property rights. Am Econ Rev. 57:347-359.

Edelenbos, J., \&Klijn, E. H. (2007). Trust in complex decision-making networks: A theoretical and empirical exploration. Administration \& Society, 39(1), 25-50.

Edwards, D. P., Tobias, J. A., Sheil, D., Meijaard, E., \&Laurance, W. F. (2014). Maintaining ecosystem function and services in logged tropical forests. Trends in ecology \& evolution, 29(9), 511-520.

FAO - ITTO (2011). Making forest concessions work to sustain forests, economies and livelihoods in tropical timber producing countries. A FAO - ITTO initiative in collaboration with SFB, CIFOR and Cirad

FAO (2015). Global Forest Resources Assessment 2015. FAO Forestry Paper No. 1. UN Food and Agriculture Organization, Rome (2015)

FAO, (1992). The forest resources of the temperate zones. In: The UN-ECE/FAO 1990 Forest Resource Assessment, Vol. 1. General Forest Resource Information, United Nations, New York,

FAO, (1994). Digitised soil map of the world, CD-ROM version 3.0. Food and Agriculture Organization of the United Nations, Rome.

FAO, (1998). FAOSTAT forestry database on (a) roundwood, sawnwood, wood-based panels and (b) pulp, paper 
and paperboard. Food and Agricultural Organization of the United Nations, FAO, Rome, 1998. Internet database: http://apps.fao.org/page/collections?subset=forestry.

Fisher R, Barrow E, de Silva J, Ingles A, Shepherd G. 2012. Improved access to forest resources: experience in informal tenure reform from IUCN's livelihoods and landscapes strategy. Gland: IUCN.

Gbedomon RC, Floquet A, Mongbo R, Salako VK, Fandohan AB, Assogbadjo AE, GlèlèKakaïR. (2016). Socioeconomic and ecological outcomes of community based forest management: a case study from TobéKpobidon forest in Benin, Western Africa. Forest Policy and Economics 64: 46-55.

Hardy, C., Phillips, N., \& Lawrence, T. (1998). Distinguishing trust and power in interorganizational relations: Forms and facades of trust. Trust within and between organisations, 64-87.

Hickey, G. M. (2008). Evaluating sustainable forest management. Ecological Indicators, 8 (2), 109-114

Hodgson, G.M (2006). What are institutions? JOURNAL OF ECONOMIC ISSUES Vol. XL No. 1

Hölzl, R. (2010). Historicising sustainability: German scientific forestry in the eighteenth and nineteenth centuries. Science as Culture, 19(4), 431-460.

Hughes, R., \&Flintan, F. (2001). Integrating conservation and development experience: $A$ review and bibliography of the ICDP literature. London: International Institute for Environment and Development.

ITTO, (1992). Criteria for the Measurement of Sustainable Tropical Forest Management. International Tropical Timber Organisation, Yokohama

J. Klaus, M. Binder, A. Wieczorek (Eds.), Governance for Industrial Transformation. Proceedings of the 2003 Berlin Conference on the Human Dimension of Global Environmental Change, Environmental Policy Group, Berlin (2004), pp. 31-51

Keeton, W. S., \& Crow, S. M. (2009). Sustainable forest management alternatives for the Carpathian Mountain region: providing a broad array of ecosystem services. Ecological Economics and Sustainable Forest Management: Developing a Trans-disciplinary Approach for the Carpathian Mountains, 109-126.

Lambin, E. F., Meyfroidt, P., Rueda, X., Blackman, A., Börner, J., Cerutti, P. O., ...\& Walker, N. F. (2014). Effectiveness and synergies of policy instruments for land use governance in tropical regions. Global Environmental Change, 28, 129-140.

Lane, C., \& Bachmann, R. (Eds.). (1998). Trust within and between organisations: Conceptual issues and empirical applications. Oxford University Press.

Larson, A. M., \& Soto, F. (2008). sDecentralisation of natural resource governance regimes. Annual review of environment and resources, 33

Laurance, W. F., Sayer, J., \&Cassman, K. G. (2014). Agricultural expansion and its impacts on tropical nature. Trends in ecology \& evolution, 29(2), 107-116.

Le Billon, P. (2001). The political ecology of war: natural resources and armed conflicts. Political geography, 20(5), 561-584.

Lebel, L., Anderies, J.M., Campbell, B. et al. (2006) Governance and the capacity to manage resilience in regional social-ecological systems. EcolSoc 11(1).

Leftwich, A., \& Hogg, S. (2007). The case for leadership and the primacy of politics in building effective states, institutions and governance for sustainable growth and social development. Background Paper, 1 .

Liefferink, D. (2006). The dynamics of policy arrangements: turning round the tetrahedron.in B. Arts, P. Leroy (Eds) Institutional dynamics in environmental governance (pp. 45-68).Springer, Dordrecht

M. BuizerWorlds Apart. Interaction Between Local Iniatives and Established PolicyWageningen University and Alterra, Wageningen (2008)

M. Miranda, J. Kool (2007). Cambodia's Family Trees: Illegal Logging and the Stripping of Public Assets by Cambodia's ElitesGlobal Witness (2007)

McDonald, G. T., \& Lane, M. B. (2004). Converging global indicators for sustainable forest management. Forest policy and economics, 6(1), 63-70.

Meyer, W., \&Baltes, K. (2004). Network Failures. How realistic is durable cooperation in global governance?. In Governance for Industrial Transformation. Proceedings of the 2003 Berlin Conference on the Human Dimensions of Global Environmental Change, Berlin: Environmental Policy Research Centre (pp. 31-51).

Milder, J. C., Arbuthnot, M., Blackman, A., Brooks, S. E., Giovannucci, D., Gross, L., ...\& Meyer, D. (2015). An agenda for assessing and improving conservation impacts of sustainability standards in tropical agriculture. Conservation biology, 29(2), 309-320.

Moffat, S., \&Cubbage, F. W. (2001). Forest certification and agenda setting. Journal of Forest Policy and Economics, 2, 307-318

N. Gunningham, N. \&Young, M.D. (1997). Toward optimal environmental policy: the case of biodiversity conservation, Ecology Law Quarterly, 24 (2) (1997), pp. 243-298

Nasi, R., \& Frost, P. (2009). Sustainable forest management in the tropics: is everything in order but the patient still dying?. Ecology and Society, 14(2).

North, D. C. (2007). Limited access orders in the developing world: A new approach to the problems of 
development (Vol. 4359). World Bank Publications.

North, D. C. (1991). Institutions STÖR. The Journal of Economic Perspectives, 5(1), 97-112.

Ophuls, W. (1973). "Leviathan or oblivion". In Toward a Steady State Economy, Edited by: Daly, H. E.215230. San Francisco: Freeman.

Oyono PR. 2007. Understanding forest tenure in Central Africa: transitions or hidden status quo in the dawn of the new century? A contribution to the listening, learning and sharing lunch of RRI. Yaounde: Rights and Resources Initiative and IUCN the World Conservation Union; $73 \mathrm{p}$.

P. Dasgupta, P. (2000). "Trust as a commodity" in D. Gambetta (Ed.), Trust: Making and Breaking Cooperative Relations, Oxford University Press, Oxford (2000), pp. 49-72

Phelps, J., Carrasco, L. R., Webb, E. L., Koh, L. P., \&Pascual, U. (2013). Agricultural intensification escalates future conservation costs. Proceedings of the National Academy of Sciences, 110(19), 7601-7606.

Poteete, A. R., \&Ostrom, E. (2004). Heterogeneity, group size and collective action: the role of institutions in forest management. Development and change, 35(3), 435-461.

Putz, F. E., Zuidema, P. A., Synnott, T., Peña-Claros, M., Pinard, M. A., Sheil, D., ...\& Palmer, J. (2012). Sustaining conservation values in selectively logged tropical forests: the attained and the attainable. Conservation Letters, 5(4), 296-303.

Robalino, J., \& Pfaff, A. (2013). Ecopayments and deforestation in Costa Rica: A nationwide analysis of PSA's initial years. Land Economics, 89(3), 432-448.

Sánchez-Azofeifa, G. A., Pfaff, A., Robalino, J. A., \&Boomhower, J. P. (2007). Costa Rica's payment for environmental services program: intention, implementation, and impact. Conservation biology, 21(5), 11651173.

Schmithüsen, F. J. (2013). Three hundred years of applied sustainability in forestry. Working papers/Forest Policy and Forest Economics Department of Forest Sciences. International series, 2013(1).

Seymour F, La Vina T, Hite K. 2014. Evidence linking community level tenure and forest condition: an annotated bibliography. Climate and Land Use Alliance. Available from: www. climateandlandusealliance.org

Silva, J. A., \&Mosimane, A. W. (2013). Conservation-based rural development in Namibia: a mixed-methods assessment of economic benefits. The Journal of Environment \&Development, 22(1), 25-50.

Sundar, N. (2000). Is Devolution Demoncratisation? Evolving State-Society Relations in Forest Management, Bastar, Central India, Draft paper for the CIFOR research project on 'Creating Space for Local Forest Management', New Delhi.

Van Laerhoven, F. (2010). Governing community forests and the challenge of solving two-level collective action dilemmas-A large-N perspective. Global Environmental Change, 20(3), 539546.

Van Lavieren, H., Spalding, M., Alongi, D. M., Kainuma, M.,Clüsener-Godt, M., \&Adeel, Z. (2012). Securing the future of mangroveS. United Nations University, Institute for Water, Environment and Health.

Vatn, A. (2005). Valuing Forest Ecosystems - An Institutional Perspective. Institutions, Sustainability, and Natural Resources, 115-134.

Wiering, M. A., \& Arts, B. J. M. (2006). Discursive shifts in Dutch river management:'deep'institutional change or adaptation strategy?. Hydrobiologia, 565(1), 327-338. 